\title{
ADAPTASI FISIOLOGIS RETINA MATA DAN TINGKAH LAKU IKAN TERHADAP CAHAYA
}

\author{
Amran Ronny Syam dan Hendra Satria \\ Peneliti pada Loka Riset Pemacuan Stok Ikan, Jatiluhur-Purwakarta \\ Teregistrasi I tanggal: 9 Pebruari 2009; Diterima setelah perbaikan tanggal: 16 Maret 2009; \\ Disetujui terbit tanggal: 3 April 2009
}

\section{ABSTRAK}

\begin{abstract}
Cahaya adalah salah satu faktor lingkungan yang penting dalam kehidupan ikan. Efek langsung yang utama adalah pada penglihatan. Cahaya yang masuk melalui mata maupun pineal region dapat mempengaruhi aktivitas ikan melalui mekanisme fisiologis retina mata ikan yang diteruskan ke pusat otak melalui sistem syaraf pusat. Adaptasi fisiologis retina mata tersebut tergantung dari struktur retina mata, kemampuan dan sensitivitas penglihatan. Pada intensitas cahaya yang relatif rendah peranan photoreseptor rod dalam retina mata lebih menonjol yang disebut sebagai scopotic vision dan pada intensitas yang lebih tinggi receptor cone relatif lebih berperan yang disebut sebagai photopic vision. Adanya stimuli cahaya menyebabkan pengaruh langsung maupun tak langsung terhadap kecepatan renang ikan dan ruaya ikan secara vertikal harian sebagai respon tingkah laku.
\end{abstract}

\section{KATAKUNCl: ekofisiologi, retina mata ikan, cahaya}

\section{PENDAHULUAN}

Cahaya dengan segala aspek yang dikandungnya seperti intensitas, sudut penyebaran, polarisasi, komposisi spektral, arah, panjang gelombang dan lama penyinaran harian, maupun musimannya; ke semua itu akan mempengaruhi baik secara langsung maupun tidak langsung terhadap tingkah laku dan fisiologis ikan (Gunarso, 1985).

Cahaya, seperti halnya faktor ekologi lain berpengaruh penting bagi kehidupan ikan. Efek langsung yang utama adalah pada penglihatan. Selain itu efek pewarnaan berpengaruh langsung terutama yang berhubungan dengan jumlah dan kualitas cahaya dan juga merangsang migrasi dan pergerakkan ikan (Lagler et al., 1977). Banyak ikan menggunakan penglihatannya untuk mencari makanan, menerima isyarat untuk tingkah laku kawin, lokasi shelter dan pengenalan orientasi. Penerimaan cahaya pada beberapa ikan bukan saja melalui mata, tetapi dapat juga melalui pineal region yang terletak dekat dengan bagian atas otak (Gambar 1). Secara umum, cahaya dapat mempengaruhi keberadaan (availability) dan tertangkapnya (catchability) ikan (Laevastu \& Hayes, 1981).

Tingkah laku hewan yang berhubungan dengan proses fisiologis seringkali berirama (rhythmic). Pada saat tertentu, siang atau malam hari atau musim atau tahunan berhubungan dengan siklus eksternal alamiah. Siklus ini dapat dipakai sebagai derajat kontrol yang pengaruhnya secara keseluruhan tergantung adanya stimuli yang sesuai dengan perubahan lingkungan. Reaksi tersebut pada dasarnya merupakan pengontrol secara ke dalam atau internal (Olla \& Studholme, in Winn \& Olla, 1972).
Tulisan ini akan membahas tentang indra penglihatan pada ikan terutama adaptasi secara fisiologis dari retina mata ikan terhadap cahaya terang dan gelap, dan perubahan intensitas cahaya terhadap tingkah laku ikan terutama aktivitas ritme harian dan musiman yang diekspresikan dalam kecepatan renang ikan.

\section{ANATOMI MATA DAN KEMAMPUAN PENGLIHATAN}

\section{Indera Penglihatan Ikan}

Bagi sebagian besar jenis ikan baik yang ekonomis penting maupun yang tidak, indra penglihat merupakan indra utama yang memungkinkan terciptanya pola tingkah laku terhadap keadaan lingkungannya. Indra penglihat ikan akan mempunyai sifat khas tertentu oleh adanya berbagai faktor seperti jarak penglihatan yang jelas, kisaran dari cakupan penglihatan, warna yang jelas, kekontrasan, kemampuan membedakan obyek yang bergerak, dan lain-lain.

Bola mata ikan pada umumnya terdiri atas kulit mata, kornea mata, iris mata, lensa mata, retina mata, dan bonggol saraf mata (Gambar 2).

Ikan sebagaimana jenis hewan lainnya mampu melihat pada siang hari yang berkekuatan penerangan beberapa ribu lux sampai pada keadaan yang hampir gelap sekalipun. Hal ini karena struktur retina mata ikan yang berisi reseptor (rod dan cone) dari indra penglihatan sangat bervariasi tergantung dari jenis ikannya. 


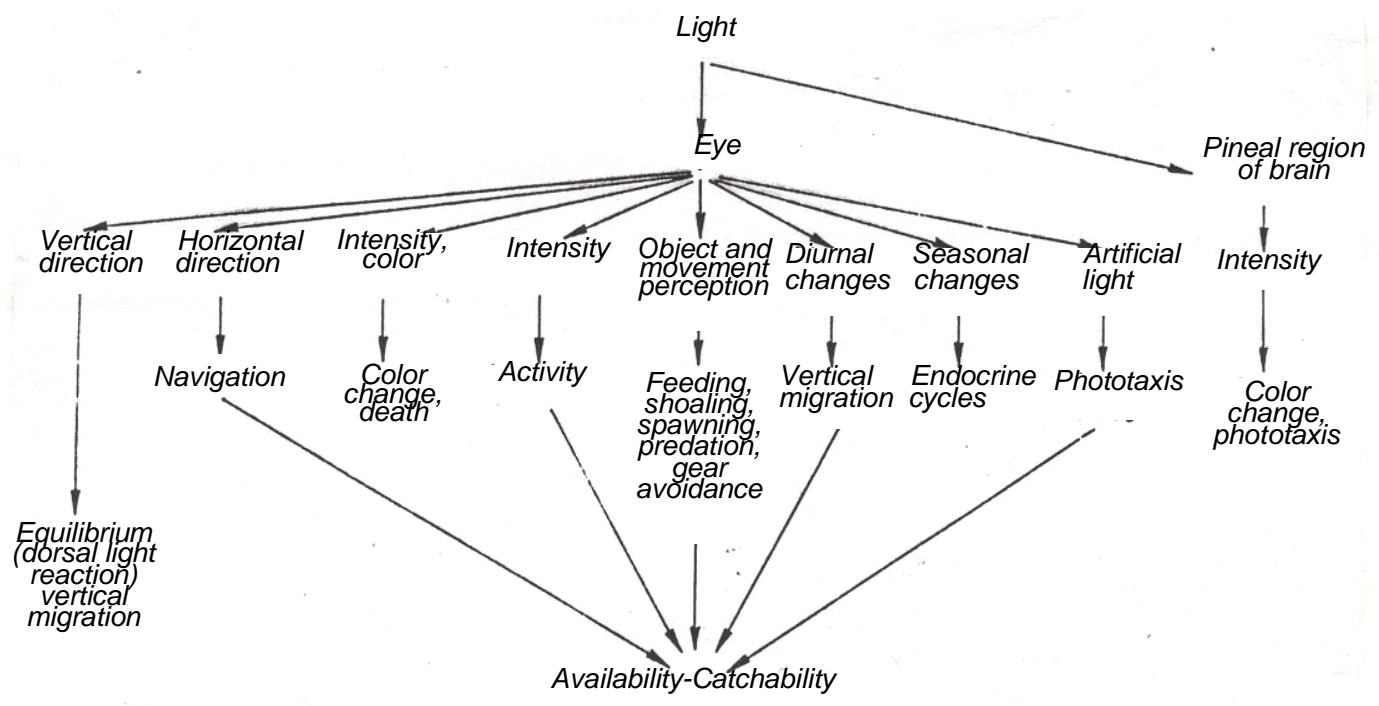

Gambar 1. Pengaruh cahaya terhadap fisiologis dan tingkah laku ikan. Sumber: Blaxter, 1965 in Laevastu \& Hayes (1981)

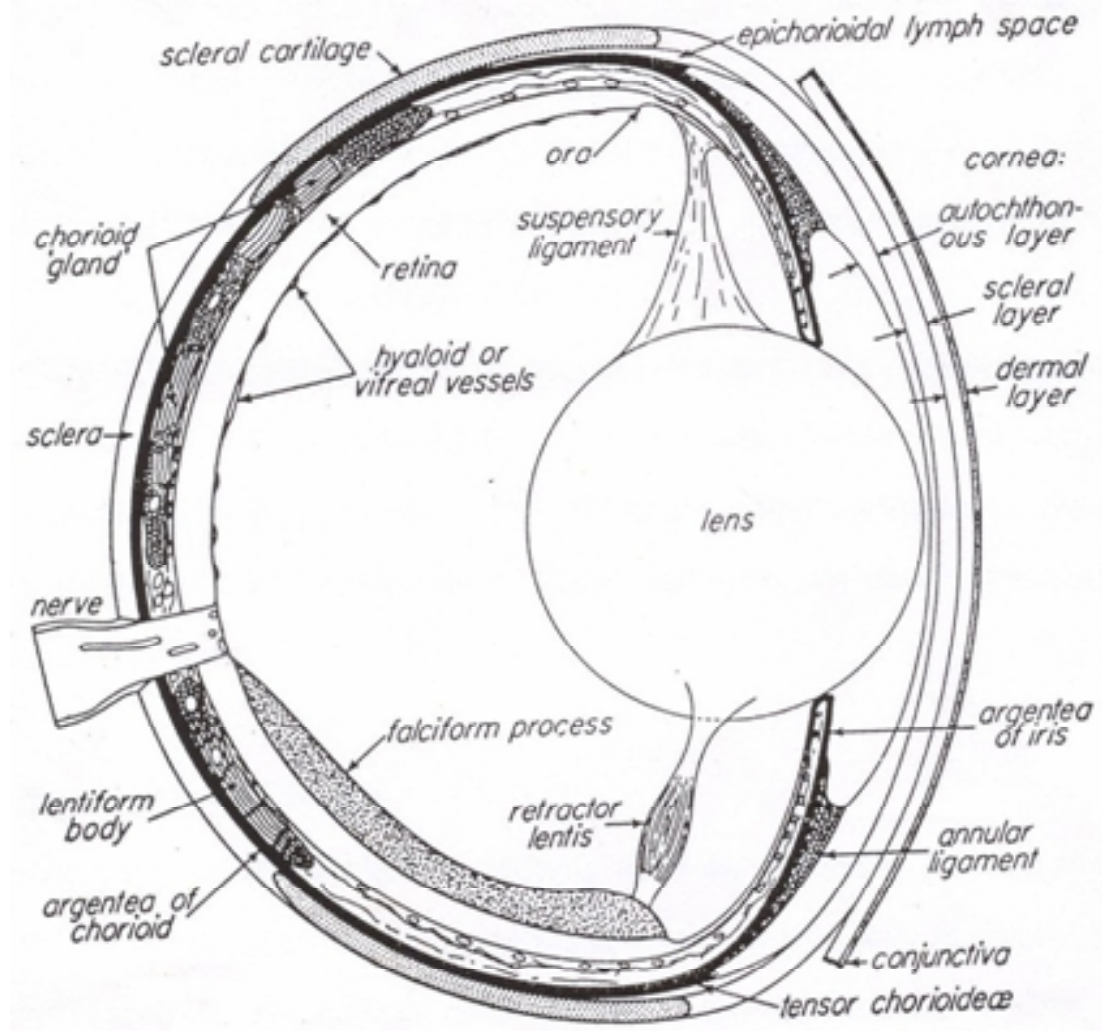

Gambar 2. Diagram penampang vertikal bentuk mata ikan teleostei. Sumber: Walls, 1942 in Hoar \& Randall (1971)

\section{Kemampuan Penglihatan Ikan dalam Air}

Ikan mampu mengindra melalui matanya pada hampir seluruh bagian dari lingkungan sekelilingnya, kecuali apa yang disebut sebagai dead zone. Jarak penglihatan ikan tergantung pada ketajaman dan kekontrasan (sifat indra penglihatan) serta keadaan penglihatan dalam air. Ikan jenis teri (Engraulis enerasi) tidak jelas atau bahkan tidak dapat membedakan ikan-ikan dari ukuran yang sama pada suatu jarak sekitar 2,8 m; ikan Atherina sp. untuk jarak sekitar 2,5 m; ikan belanak pada suatu jarak sekitar 2,7 m (Gunarso, 1985). 
Berbagai jenis ikan yang banyak kita jumpai pada lapisan air yang dangkal yang banyak menerima cahaya matahari pada waktu siang, pada umumnya ikan-ikan tersebut mampu membedakan warna; sedangkan beberapa jenis ikan penghuni laut dalam di mana tidak semua jenis cahaya dapat menembusnya, maka banyak di antara mereka yang tidak dapat membedakan warna.

Ketajaman warna yang dapat dilihat (kekontrasan) oleh mata ikan merupakan hal yang penting untuk memungkinkan ia membedakan benda-benda dengan ukuran tertentu dari suatu jarak yang cukup jauh. Semakin kabur tampaknya sesuatu benda bagi mata ikan, maka kemampuan menangkap kekontrasan benda tersebut semakin berkurang.

\section{Sensitivitas terhadap Cahaya}

Seperti yang telah dijelaskan bahwa ikan mempunyai kemampuan melihat pada waktu siang dengan kekuatan penerangan ratusan ribu lux dan dalam keadaaan hampir gelap sama sekali menunjukkan bahwa kuat penerangan itu erat kaitannya dengan tingkat sensitivitas penglihatan ikan, dengan kata lain berkurangnya derajat penerangan akan menyebabkan berkurangnya jarak penglihatan ikan.

Telah diketahui bahwa berbagai jenis ikan laut pada umumnya selalu berusaha untuk meningkatkan sensitivitas mereka, oleh sebab itu beberapa jenis ikan mempunyai mata yang besar bahkan pada beberapa jenis ikan laut dalam, mata tersebut sangat besar dengan pupil yang besar dan reseptor rod yang sangat panjang serta adanya pergerakkan photomekanik dari elemen-elemen retina. Beberapa spesies ikan bahkan mempunyai apa yang dinamakan tapetum lucidum yaitu elemen tertentu yang membantu memperbesar jumlah cahaya yang diterima oleh reseptor (cone dan rod) sebagaimana halnya reflektor pada lampu blits; sedangkan untuk dapat mempertahankan jumlah cahaya maksimum yang dapat diterima oleh reseptor, beberapa jenis ikan memiliki retina dengan pigmen retina yang banyak. Pigmen retina tersebut mempunyai kemampuan menyerap sinar yang terlalu banyak sebelum mencapai reseptor.

Sensitivitas mata ikan laut pada umumnya sangat tinggi. Kalau cahaya biru hijau yang mampu diterima mata manusia hanya $30 \%$, mata ikan mampu menerimanya sampai $75 \%$. Pada retina mata beberapa jenis ikan laut (perairan dalam) menerimanya sampai $90 \%$. Beberapa jenis ikan yang hidup di perairan pantai memiliki sensitivitas mata yang tinggi sehingga dapat mengindra mangsanya dari kejauhan $100 \mathrm{~m}$ sejak pagi sampai senja hari (Woodhead, 1966 in Gunarso, 1985).

\section{Adaptasi Fisiologis Retina Mata Ikan}

\section{Mekanisme Adaptasi}

Adaptasi adalah proses penyesuaian secara bertahap yang dilakukan oleh suatu organisme terhadap kondisi lingkungan yang baru. Secara umum, proses adaptasi dapat digambarkan seperti pada skema yang disajikan pada Gambar 3.

Afektor merangsang reseptor, kemudian melalui transmiter informasi tersebut diteruskan ke effektor atau melalui forward transmiter, selanjutnya informasi diteruskan ke regulator. Sebagai hasil kerja effektor adalah beberapa outputyang dapat menstimulasi feed back transmiter yang akan kembali berinteraksi dengan regulator (Gambar 3).

Secara ekofisiologis, hubungan antara afektor (cahaya), kemudian oleh mata terutama pada bagian retina yang di dalamnya terdapat photoreseptor (cone dan rod) merubah dari energi cahaya ke energi listrik (transmiter) sehingga dapat diterjemahkan oleh sistem syaraf dan diteruskan ke otak sebagai pusat regulator. Impuls dari otak ini yang akan menghasilkan suatu aktivitas. Dikatakan juga bahwa dalam photoreseptor cone dan rod terdapat sel-sel horisontal yang mengandung Gamma-Aminobutyric Acid sebagai syaraf-syaraf penerjemah (neurotransmitter). Selain itu, terdapat syaraf yang keluar dari organ cristal cerebelli di dalam medula oblongata pada otak bagian belakang ikan yang berfungsi untuk mengadakan schooling atau berenang secara berkelompok (Fernald in Evans, 1993).

\section{Adaptasi dalam Kondisi Terang dan Gelap}

Pada sebagian besar ikan teleostei, pergerakkan photomekanik dari elemen-elemen retina yang disebut sebagai retinomotor dapat mengontrol intensitas cahaya. Adaptasi retina mata dalam kondisi cahaya gelap, di mana lapisan sel-sel retina bagian luar yang disebut pigmen epitelium menipis sepanjang lapisan sel visual (Gambar 4).

Rod pada segmen luar tertarik ke dalam dan bersamaan dengan segmen luar dari cone bergerak melewati rod. Pada kondisi adaptasi cahaya terang, pigmen epitelium menyebar luas sepanjang sel-sel visual ketika terjadi perubahan panjang tangkai rod dan cone yang bergerak untuk mengatur melamin dalam pigmen epitelium (Hoar \& Randall, 1971). 
(A)

\section{Lingkungan}

Afektor/Trigger (stimuli dari lingkungan luar)

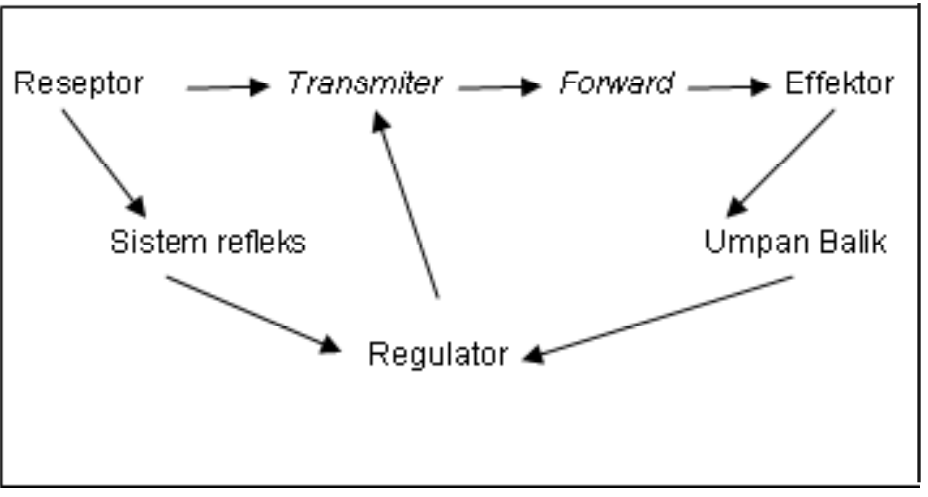

Gambar 3. Skema umum mekanisme adaptasi suatu organisme terhadap lingkungannya. Sumber: Dualantus (1996)

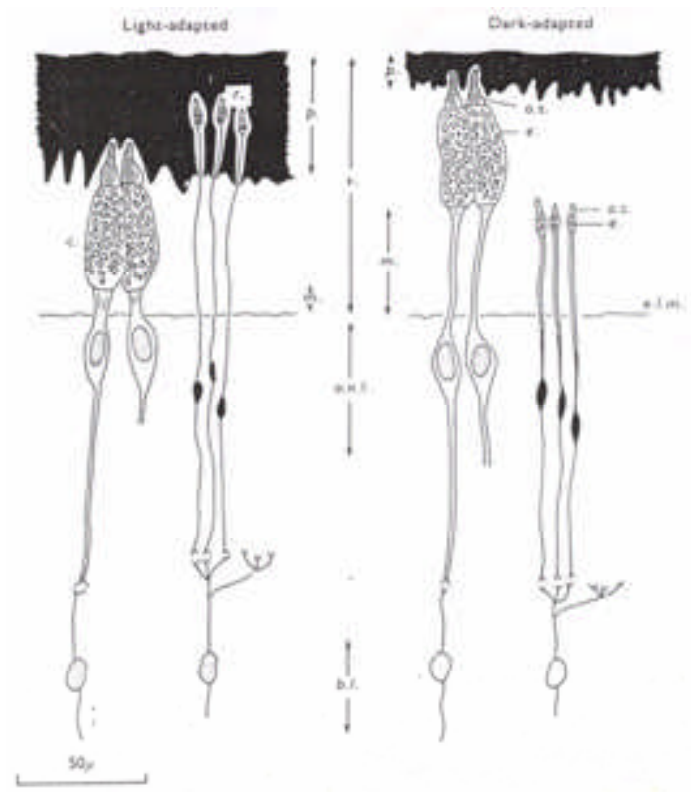

Gambar 4. Penampang semi diagramatik dari retina mata ikan Clupea dalam kondisi adaptasi cahaya terang dan gelap.

Keterangan: b.I.: lapisan bipolar; C.: cone; e.: ellipsoid; e.l.m.: membran pembatas eksternal; m.: panjang myoid cone; o.n.I.: lapisan inti luar; o.s.: segmen bagian luar; p.: pigmen epitelium; r.: rod; v.: lapisan sel visual

Sumber: (Blaxter \& Jones, 1967 in Hoar \& Randall, 1971)

Pergerakkan fotomekanik elemen retina pada ikan juvenil (ikan muda) dari Oncorhynchus dalam adaptasinya dengan kondisi cahaya terang berlangsung selama 20-25 menit dan pada cahaya gelap membutuhkan waktu sekitar sejam (Brett \& Ali, 1958 in Hoar \& Randall, 1971).

Pada ikan teleostei, pada umumnya memiliki jenis retina duplek dengan pengertian bahwa dalam retina mereka terdapat kedua jenis reseptor itu yang dinamakan rod dan cone. Perbedaan distribusi kedua reseptor tersebut pada berbagai jenis ikan erat kaitannya dengan pemanfaatan indra penglihatan dalam lingkungan hidupnya.
Pada jenis ikan wolf fish (Anarhinchas lupus) dan dragonet (Callionymus lyra) terdapat peningkatan cone yang sangat menyolok pada bagian dorsal retina mata, oleh karena penglihatannya sering ke arah bawah. Pada jenis ikan Labridae dan Gadoidae (seperti ikan Pollack Pollachius pollachius, Coalfish Pollachius virens, Cod Gadus morhua, dan Hake Merluccius merluccius) mempunyai penyebaran cone yang relatif merata pada seluruh bagian retina matanya atau sedikit terkonsentrasi pada bagian temporal. Hal ini menunjukan kebiasaan ikan tersebut memburu mangsanya baik yang hidup dekat dasar maupun di daerah pelagis, dengan arah penglihatan ke depan (Engstrom, 1963 in Gunarso, 1985). 
Pada berbagai ikan pelagis (seperti pada famili Clupeidae) konsentrasi cone sangat padat pada daerah antara ventro temporal yang dibatasi oleh adanya daerah temporalis. Pada jenis Sardinops caerulea dan Alosa sapidissima, daerah temporalis tersebut sangat jelas dan bahkan reseptor hampir sepenuhnya terdiri atas cone; sedangkan rod hampir tidak ada atau tidak ada sama sekali (O'Connell, 1963 in Gunarso, 1985). Sebaliknya, pada jenis ikan dasar atau jenis ikan yang hampir sepanjang hidupnya tinggal di daerah yang nyaris tak terjangkau sinar matahari mempunyai reseptor pada retina matanya hanya terdiri atas rod (misalnya pada ikan bertulang rawan seperti Mystelus sp., Myliosates sp., dan Megaprion sp.). Hasil perhitungan banyaknya rod pada beberapa jenis ikan laut-dalam menunjukan jumlah rod lebih dari 25 juta per $\mathrm{mm}^{2}$ retina. Hal ini menunjukkan bahwa mungkin mata jenis ikan lautdalam yang mempunyai tingkat sensitivitas yang lebih tinggi (Walls, 1942 in Gunarso, 1985).

Pigmen visual pada ikan memberikan fotosensitivity optimal dari kualitas cahaya untuk menyesuaikan keadaan lingkungannya. Pada ikan air tawar kebanyakkan retinanya terdiri atas porphyropsin sebagai pigmen visual utama, sedangkan rhodopsin dan chrysopsin ditemukan pada retina ikan laut (Mc. Keown, 1984). Pada ikan salmon, pigmen visual juga berubah untuk melakukan preadaptasi terhadap lingkungan laut selama smoltification (Bridges \& Delisle, 1974).

Trematomus bernacchii yang merupakan salah satu jenis ikan notothenioids (Nelson, 1984) adalah jenis ikan yang memiliki sistem sensor ekofisiologi di antaranya sistem visual yang mampu mereduksi cahaya ke matanya pada kondisi cahaya redup (cahaya senja). Retina mata jenis ikan tersebut didominansi oleh cone ganda dan tunggal dengan jumlah sel cone 13, rod 27, dan ganglion 5 per $\mathrm{mm}^{2}$. Rasio jumlah cone dan rod: ganglion adalah 8:1 menunjukkan suatu rasio sensitivitas yang rendah (Jensen \& Rankin, 1993).

Beberapa jenis ikan predator pelagis seperti ikan amberjack (Seriola dumerili), dolpin (Coryphaena hippurus), barakuda (Sphyraena barracuda), dan layaran (Istiophorus albicans) memiliki konsentrasi cone yang tinggi walaupun tidak jelas adanya pengelompokkan pada satu bagian dari retina mata; sedangkan pada beberapa jenis ikan tuna seperti ikan cakalang (Katsuwonus pelamis), black fin (Thunnus atlanticus), little tuna (Euthynnus alletteratus), dan jenis makerel besar (Scomberomorus cavalla) memiliki cone yang terkonsentrasi sangat tinggi pada bagian ventro temporal yang jumlahnya 3 kali cone pada seluruh bagian retina lainnya. Sedangkan pada ikan makerel (Scomber scombrus), jack mackerel (Trachurus symmetricus), makerel dari pasifik (Pneumatophorus diego), Scomber japonica dan Seriola quingquevadiata penyebaran cone pada retinanya merata pada seluruh retina matanya yang berarti kekuatan penglihatan dari seluruh bagian retina mereka sama kuatnya.

\section{Respon Ikan terhadap Stimuli Cahaya}

Ikan mempunyai respon terhadap rangsangan yang disebabkan oleh cahaya yang besarnya 0,01 lux atau sekecil 0,001 lux sekalipun. Dari hasil pengamatan echosounder, diketahui bahwa cahaya lampu yang masuk ke dalam laut mampu diindra oleh mata manusia (kedalaman $15 \mathrm{~m}$ ) ternyata mampu memikat ikan yang berada pada kedalaman $28 \mathrm{~m}$. Pada jenis ikan yang bersifat fototaxis positif (seperti Sprateloides, Saury Cololabis saira, dan ikan herring muda) yaitu bergerak ke arah sumber cahaya, sebaliknya ada yang bersifat fototaxis negatif (yang menjauhi sumber cahaya) seperti ikan herring dewasa.

Hasil penelitian Olla \& Studholme in Winn \& Olla (1972) pada ikan blue fish (Pomatomus saltatrix) dalam kondisi laboratorium menunjukkan bahwa aktivitas harian dan musiman yang diukur dengan kecepatan renang ikan (cm/det) meningkat pada siang hari sesuai dengan ritme meningkatnya intensitas cahaya (Gambar 5 dan 6) dan menurun ketika menjelang sore hari. Begitu juga tingkah laku formasi kelompok pada jenis ikan tersebut terjadi peningkatan di siang hari daripada malam hari (Gambar 7).

Tingkah laku ikan yang ditandai dengan kecepatan renang ikan dan pembentukan ukuran formasi kelompok (schooling group size) berirama sesuai dengan ritme photoperiod. Hasil yang diperoleh juga menunjukkan kecepatan renang ikan pada siang hari lebih tinggi daripada malam hari berdasarkan pada lamanya pencahayaan atau photoperiod (Gambar 8).

Demikian juga adaptasi retina ikan uji terhadap kondisi bercahaya dan kondisi gelap berhubungan dengan pengontrolan internal yang diekpresikan dalam perpindahan cone dan pigmen epitelium dari ikan blue fish muda tersebut yang berukuran $14-17 \mathrm{~cm}$. Sebagai gambaran pergeseran posisi cone yang dihubungkan dengan ritme kecepatan renang selama sehari lebih, disajikan pada Gambar 9. 


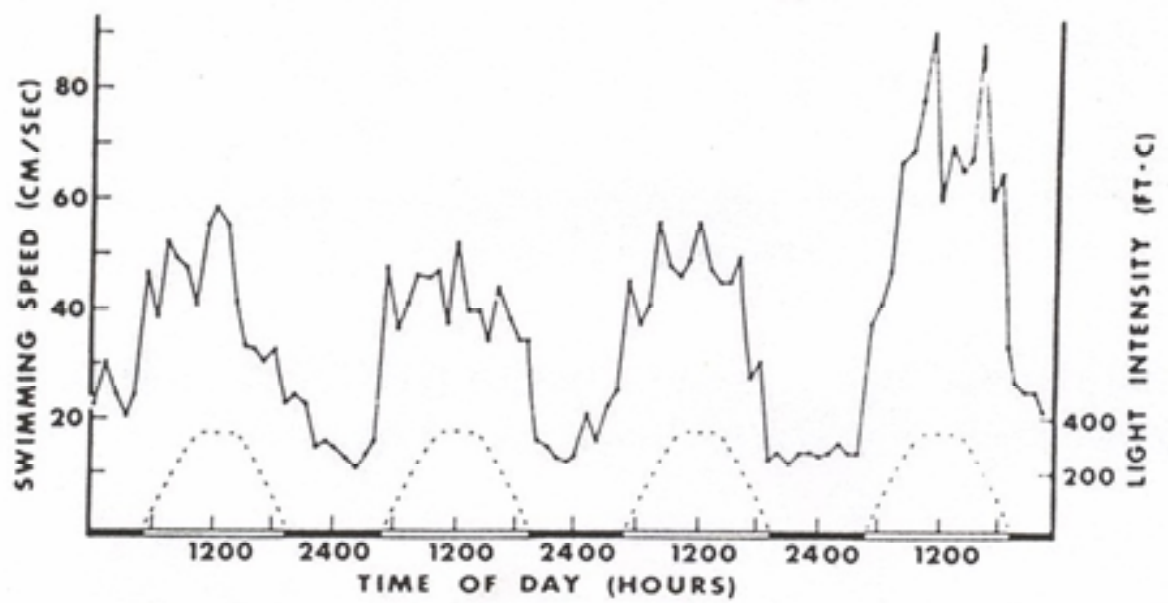

Gambar 5. Median kecepatan renang ikan yang diukur setiap jam selama 4 hari pada kondisi photoperiod 14,15 jam. Perubahan intensitas cahaya digambarkan dalam garis putus-putus. Sumber: (Olla \& Studholme in Winn \& Olla, 1972)

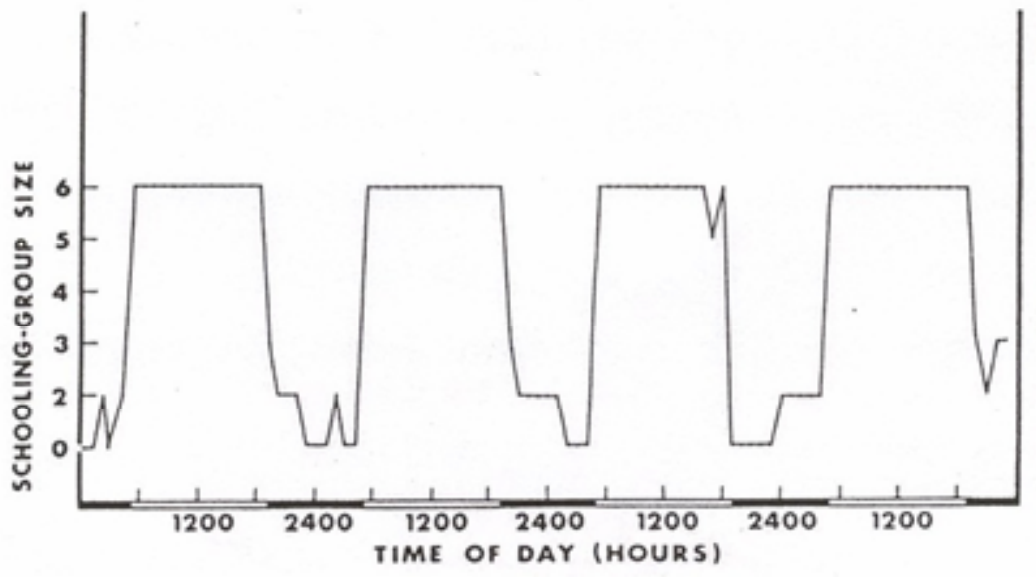

Gambar 6. Median kecepatan renang ikan yang diukur setiap 5 menit selama 24 jam pada kondisi photoperiod 12,5 jam. Perubahan intensitas cahaya digambarkan dalam garis putus-putus. Sumber: (Olla \& Studholme in Winn \& Olla, 1972)

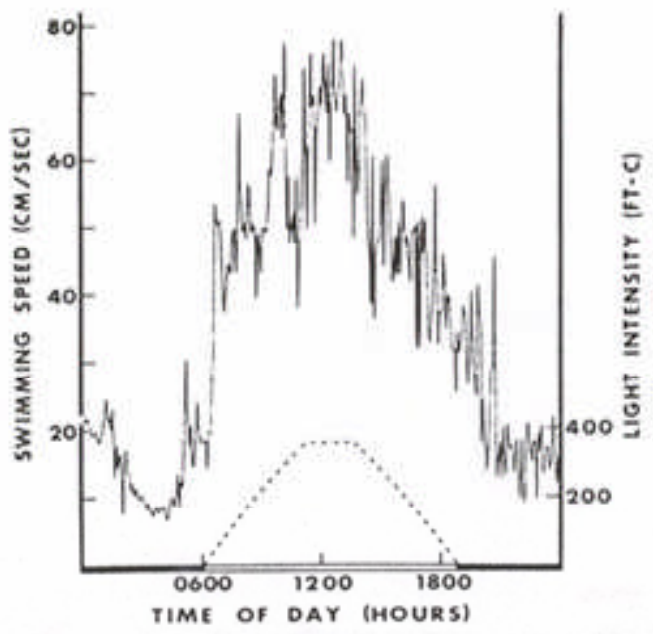

Gambar 7. Median ukuran schooling group yang diukur setiap jam selama 4 hari pada kondisi photoperiod 14,15 jam.

Sumber: (Olla \& Studholme in Winn \& Olla, 1972) 


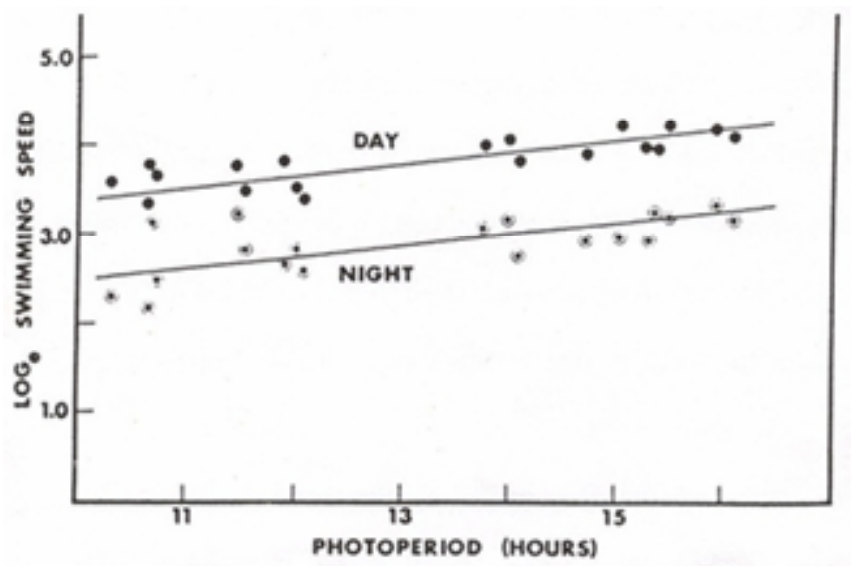

Gambar 8. Kecepatan renang ikan pada siang dan malam hari selama 4 hari yang diukur pada 19 photoperiod yang berbeda.

Sumber: (Olla \& Studholme in Winn \& Olla, 1972)

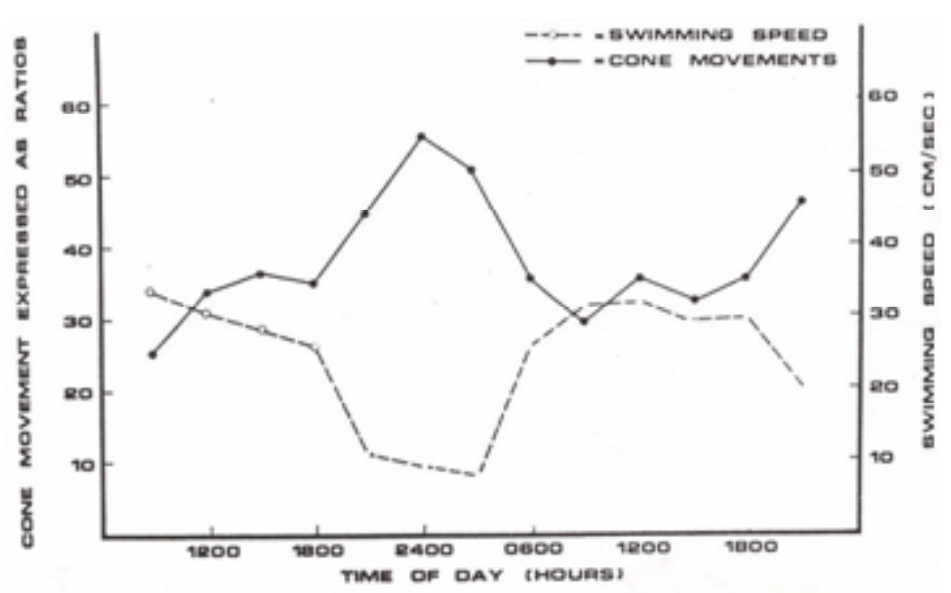

Gambar 9. Nilai tengah posisi cone (sel reseptor pada retina mata ikan) yang dibandingkan dengan aktivitas renang ikan.

Sumber: (Olla \& Studholme in Winn \& Olla, 1972)

Dari gambar tersebut terdapat 2 kurva yang menunjukkan posisi cone dalam beradaptasi terhadap cahaya gelap di mana kecepatan renang ikan blue fish rendah. Dari hal tersebut dapat dikatakan bahwa aktivitas renang ikan menurun pada jam-jam fase gelap di alam, sebaliknya adaptasi posisi cone pada kondisi cahaya terang dan aktivitas renang ikan meningkat pada jam-jam selama fase terang alamiah.

Dari uraian di atas dapat dikatakan bahwa perubahan intensitas cahaya dapat berpengaruh pada aktivitas ikan dan pergerakkan reseptor cone dan rod pada elemen retina. Sehubungan dengan hal tersebut, diagram di bawah ini (Gambar 10) menunjukkan tingkah laku makanan pada ikan salmon pasifik (Oncorhynchus), ikan trout (Salmo dan Salvelinus) ketika memburu mangsanya, diketahui bahwa terjadi pergeseran peranan reseptor cone ke reseptor rod pada saat cahaya memudar. Intensitas cahaya antara
0,1 dan 100 foot candle atau lebih, reseptor cone sangat berperan memberikan informasi terhadap bayangan pergerakkan mangsanya. Intensitas antara 0,1 dan 0,0001 dapat memungkinkan kegiatan memakan (feeding) berhenti dan shcooling berpencar (Ali, 1959 in Lagler et al., 1977).

\section{Ruaya secara Vertikal Harian}

Dengan adanya rangsangan cahaya, Hela \& Laevastu (1961); Laevastu \& Hayes (1981) mengelompokkan ikan berdasarkan pada ruaya secara vertikal hariannya (Gambar 11) ke dalam 6 kelompok, yaitu:

a. Kelompok jenis ikan pelagis yang muncul sedikit di atas termoklin pada waktu siang hari. Jenis ikan ini akan beruaya ke lapisan permukaan pada waktu sore hari, sedangkan pada malam harinya mereka menyebar pada lapisan antara permukaan dengan 


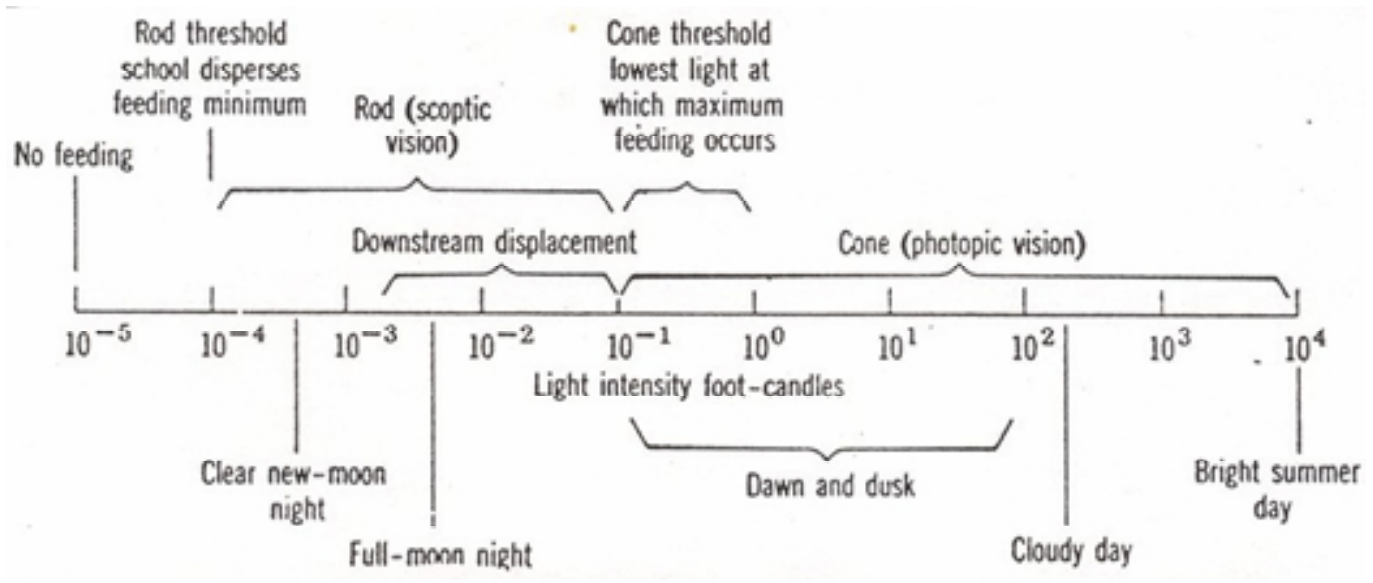

Gambar 10. Diagram yang menunjukan tentang respon ikan salmon (Oncorhynchus) berupa penglihatan terutama pada reseptor rod dan cone dalam retina mata terhadap berbagai intensitas cahaya yang berbeda termasuk intensitas cahaya pada kondisi alamiah.

Sumber: (Ali, 1959 in Lagler et al., 1977)

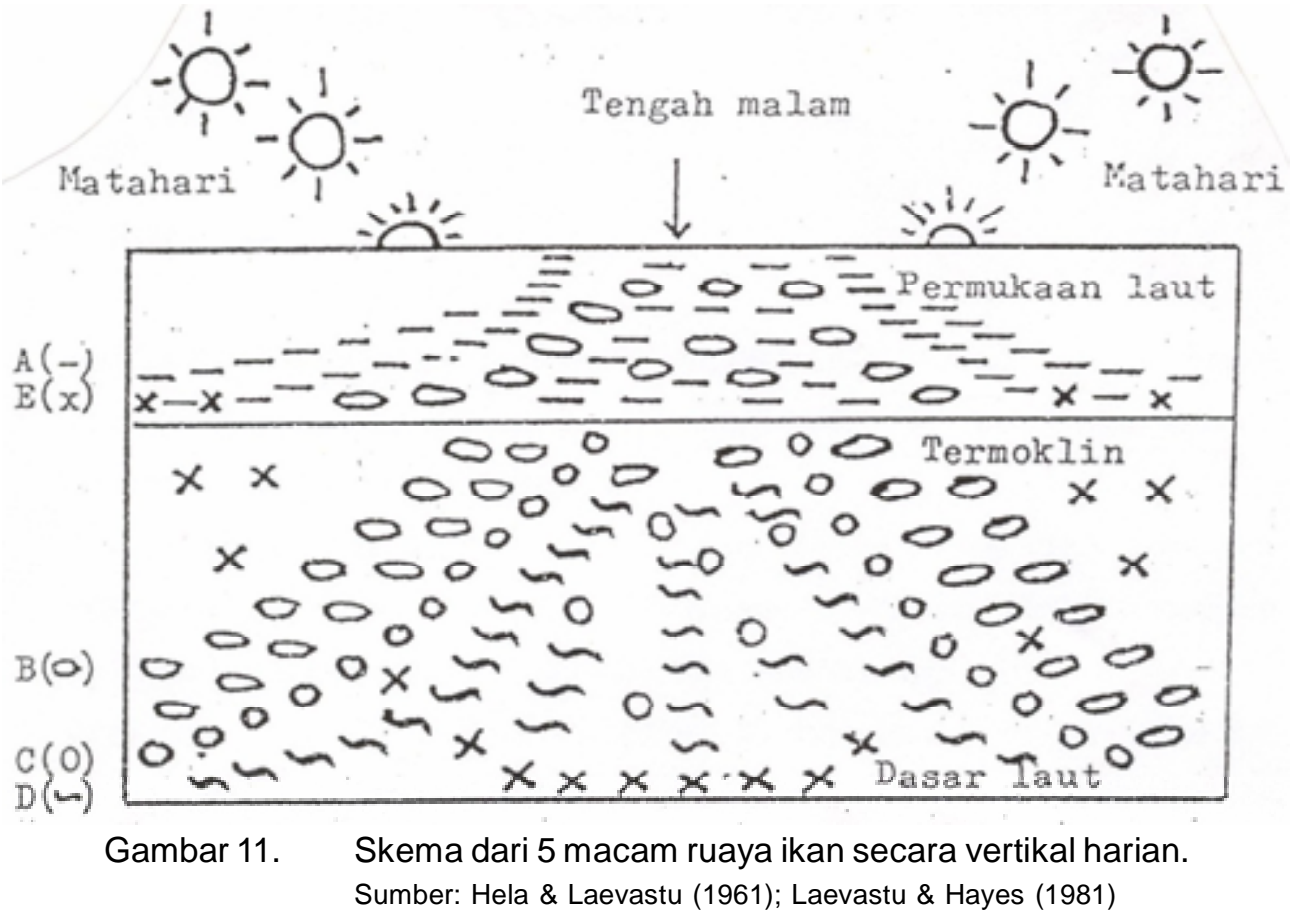

termoklin. Kemudian pada waktu matahari terbit mereka akan menghindar dari lapisan di atas termoklin tersebut.

b. Jenis ikan pelagis yang muncul di bawah termoklin pada waktu siang hari dan beruaya melalui termoklin ke lapisan permukaan pada waktu sore hari, kemudian menyebar pada lapisan antara permukaan dengan dasar perairan selama malam hari dan sebagian dari mereka berada di atas termoklin. Pada waktu matahari terbit mereka akan turun ke lapisan yang lebih dalam.

c. Jenis ikan pelagis yang muncul di bawah termoklin selama sore hari, malam harinya menyebar di antara termoklin dan dasar perairan bahkan mungkin turun ke lapisan yang lebih dalam pada waktu matahari terbit.

d. Ikan dasar berada pada perairan dekat dasar di siang hari, beruaya dan menyebar ke lapisan di bawah termoklin (kadang di atas termoklin) pada sore hari kemudian turun ke dasar atau lapisan yang lebih dalam pada waktu matahari terbit.

e. Jenis-jenis ikan yang menyebar di seluruh kolom air selama siang hari dan turun ke dasar perairan pada malam hari.

f. Jenis ikan pelagis dan demersal yang tidak mempunyai migrasi harian yang jelas. 
Pada umumnya ikan pelagis akan muncul ke lapisan permukaan sebelum matahari terbenam dan mereka membentuk kelompok. Sesudah matahari terbenam mereka menyebar ke dalam kolom air dan mencari lapisan air yang lebih dalam pada waktu siang hari (kelompok A, B, dan C). Bagi ikan demersal, mereka menyebar ke dalam kolom air selama malam hari (kelompok D).

\section{Implikasi Cahaya terhadap Perikanan Tangkap}

Beberapa aspek tingkah laku ikan seperti cara makan, pengelompokkan dan ruaya harian banyak dipengaruhi oleh cahaya, hal ini ada kaitannya dengan fitoplankton yang menjadi makanan mereka. Beberapa jenis fitoplankton yang melakukan fotosintesis dan juga menghasilkan toksin (racun), menyebabkan ikan menghindar dari daerah tersebut. Hal itu dapat dikatakan bahwa ruaya harian beberapa jenis ikan tertentu dapat dipengaruhi oleh plankton sebagai rentetan akibat dari cahaya tersebut. Dengan mengetahui ruaya secara vertikal harian pada suatu jenis ikan, maka waktu untuk melakukan penangkapan dan alat penangkapan dapat ditentukan.

Dari beberapa hasil penelitian menunjukkan adanya perbedaan tingkah laku ikan dalam merespon warna cahaya di sekitar lingkungannya (Razak et al., 2005). Hasil penelitian Kuroki in Razak et al., 2005 menunjukkan bahwa warna biru dan orange tergolong efektif dalam mengumpulkan ikan; sedangkan Kawamoto in Razak et al., 2005 berpendapat lain yaitu warna biru dan kuning. Selain kedua peneliti tersebut, Mubarak in Razak et al., 2005, mengatakan bahwa cahaya biru merupakan berkas cahaya yang dapat menimbulkan daya tarik pada juvenil ikan kerapu tikus (Cromileptes altiveriss) mendekati sumber cahaya. Berkas cahaya biru tersebut memiliki nilai iluminasi paling besar dibandingkan dengan berkas cahaya putih dan merah.

Dengan demikian, maka karakteristik retina mata ikan dapat dijadikan acuan dalam menentukan tingkah laku ikan yang pada akhirnya dapat dirancang alat tangkap, dan waktu yang tepat untuk menangkap ikan tersebut. Sebagai contoh, jika merancang alat tangkap bagan diperlukan asesoris dalam mengumpulkan ikan sebelum jaring pada alat bagan tersebut diangkat, hendaknya lampu yang digunakan tersebut dilapisi warna biru atau orange atau kuning . Demikian juga asesoris umpan buatan dalam alat tangkap pancing hendaknya lebih didominansi dengan warna biru, atau orange, atau kuning, atau kombinasi ketiga warna tersebut sehingga merangsang daya tarik ikan pada umumnya.

\section{KESIMPULAN}

1. Cahaya dapat berpengaruh baik secara langsung maupun tak langsung terhadap tingkah laku ikan terutama yang menyangkut aktivitas renang dan formasi kelompok secara harian dan musiman.

2. Pada sebagian besar ikan pemanfaatan mata mereka adalah untuk menerima cahaya dan memahami gerakkan di sekelilingnya, melalui suatu mekanisme fisiologis retina mata yang diteruskan ke otak melalui sistem syaraf.

3. Retina mata ikan yang di dalamnya terdapat berbagai elemen reseptor (cone dan rod), jumlah dan distribusinya dapat menjadi petunjuk tingkah laku ikan dan kondisi lingkungannya.

4. Pada kondisi cahaya redup reseptor rod berperan sebagai scoptic vision dan pada kondisi cahaya terang reseptor cone berperan sebagai photopic vision.

5. Informasi mengenai ekofisiologis ikan akan bermanfaat dalam mempelajari tingkah laku ikan yang pada akhirnya dapat diaplikasikan ke dalam rancang bangun alat penangkapan ikan yang sesuai dengan sasaran tangkapan.

\section{PERSANTUNAN}

Naskah ini hasil review desk studi, baik di perpustakaan Loka Riset Pemacuan Stok Ikan, Jatiluhur-Purwakarta dan Institut Pertanian Bogor, Bogor, yang dilakukan pada tahun 2008-2009.

\section{DAFTAR PUSTAKA}

Bridges, C. D. \& C. E. Delisle. 1974. Evolution of visual pigment. Exp. Eye.Res. 18: p. 32-322.

Dualantus. 1996. Fisiologi Hewan Air. (Suatu Rangkuman Kuliah). Program Kerja Sama Jurusan Perikanan. Fakultas Pertanian. Universitas Palangkaraya dengan Program Studi Manajemen Sumber Daya Perikanan. Fakultas Perikanan. Institut Pertanian Bogor. Bogor.

Evans, D. H. 1993. The Physiology of fishes (Eds). Marine Science Series. CRS Press. Inc. Boca Raton. p. 161-189.

Gunarso, W. 1985. Tingkah Laku Ikan dalam Hubungannya dengan Alat, Metode, dan Taktik Penangkapan. Fakultas Perikanan. Jurusan 
Pemanfaatan Sumber Daya Perikanan. Institut Pertanian Bogor. Bogor.

Hela, I. \& T. Laevastu. 1961. Fisheries Hydrography. Fishing News (Books) Ltd. Ludgate House. 110 Fleet Street. London. E.C.4.

Hoar, W. S. \& D. J.Randall. 1971. Fish Physiology. Academic Press. New York. V: p. 1-32.

Jensen, F. B. \& J. J. Rankin. 1993. Fish Ecophysiology. Chapman \& Hall. London. p. 341374.

Lagler, K. F., J. E. Bardach, R. R. Miller, \& D. R. M. Passino. 1977. Ichthyology. John Wiley \& Sons. New York. p. 411-457.

Laevastu, T. \& M. I. Hayes. 1981. Fisheries Oceanography and Ecology. Fishing News Books Ltd. Farnham, Surrey, England. p. 4-23.
Mc. Keown, B. A. 1984. Fish Migration. Timber Press. Portland. Oregon.

Nelson, J. S. 1984. Fishes of the World. John Wiley \& Sons. New York.

Razak, A., K. Anwar, \& M. S. Baskoro. 2005. Fisiologi Mata Ikan. Departemen Pemanfaatan Sumber Daya Perikanan. Fakultas Perikanan dan IImu Kelautan. Institut Pertanian Bogor. Bogor.

Winn, H. E. \& B. L. Olla. 1972. Behavior of Marine Animals: Current Perspectives in Research. Plenum Press. New York. Vol.2 (Vertebrates). 503 pp. 